\title{
Polymerase chain reaction for the detection of Neisseria gonorrhoeae in clinical samples
}

\author{
B S W Ho, W G Feng, B K C Wong, S I Egglestone
}

\begin{abstract}
Aims: To evaluate the use of a $\operatorname{cppB}$ gene derived polymerase chain reaction (PCR) assay for direct detection of Neisseria gonorrhoeae in clinical samples.

Methods: A PCR assay was performed on $33 \mathrm{~N}$ gonorrhoeae strains and 12 other Neisseria species and other normal genital flora to evaluate the specificity of the chosen $c p p B$ primers. The assay was subsequently evaluated with 52 clinical swab samples collected from China.

Results: An amplified product of 390 base pairs (bp) was observed with all the $N$ gonorrhoeae strains, each of these products on digestion with the restriction enzyme MspI produced two bands of 250 bp and 140 bp respectively. This set of primers did not produce any amplified product of the expected length with the other non-gonococcal strains tested. For the 52 clinical swabs, 34 were culture positive and $P C R$ successfully detected all these positives. In addition the PCR was positive for two swabs which were culture negative but positive for $\boldsymbol{N}$ gonorrhoeae antigens when tested with the ELISA method (Gonozyme).

Conclusions: This PCR assay is a promising diagnostic tool for detection of gonococci directly from clinical swab samples. Further evaluation is necessary.
\end{abstract}

The use of hybridisation with DNA probes as a tool for detection of gonococci in urogenital specimens has been investigated extensively in recent years. Probes using nucleotide sequences of the pilin gene, ${ }^{1}$ the IgAl protease gene, ribosomal $\mathrm{RNA}^{34}$ and the cryptic plasmid have been reported. The pilin genes of the gonococci have more than one copy, but they are highly homologous with those of the meningococci. All gonococci have a single copy of the IgAl protease gene, ${ }^{2}$ however detection is difficult when few organisms are present in the clinical sample. The rRNA-derived oligonucleotide probes to different regions of the $16 \mathrm{~S}$ ribosomal RNA have been reported to have a sensitivity and specificity of $100 \%$, but the exact sequences of these probes have not been published. Gonococcal clinical isolates have several plasmids. ${ }^{6}$ The smallest of these which is present in about $96 \%$ of strains is approximately $4 \cdot 2$ kilobases $(\mathrm{kb})$ in size and its function is unknown. The use of cryptic plasmidderived probes for DNA hybridisation was thought to have limited application for the detection of gonococci in clinical isolates. It has recently been shown by Hagblom et al that the polypeptide product of the $c p p B$ gene of the cryptic plasmid $\mathrm{pJD} 1$ is also produced by plasmid-free strains and that a copy of this gene was present in the gonococcal chromosome of all strains tested. ${ }^{7}$ However the possible crossreaction with plasmids from $N$ meningitidis and $N$ lactamica needs to be borne in mind. ${ }^{8}$ The problem of low gene copy number has been overcome by the development of the polymerase chain reaction (PCR) where, theoretically, even a single gene copy would be sufficient for amplification.

As the complete nucleotide sequence of the cryptic plasmid is known ${ }^{9}$ it was decided to develop a PCR using primers derived from the integrated regions of the $c p p B$ gene. During the course of the present study, Torres et al reported the evaluation of a cryptic plasmidderived DNA probe in a dot-blot hybridisation assay. ${ }^{10}$ The probe, consisting of a $237 \mathrm{bp}$ segment of the plasmid-encoded gene $c p p B$ labelled with digoxigenin-11-dUTP, was evaluated using both known bacterial isolates and clinical specimens. The present paper describes the development of a PCR assay for $N$ gonorrhoeae in which a 390 base pair (bp) DNA fragment of the $c p p B$ gene was amplified and its performance with that of culture compared using urethral and cervical swabs from patients with acute urethritis.

Methods

Bacterial strains

The $N$ gonorrhoeae strains used were all clinical isolates recovered from urethral or cervical swabs by inoculation onto modified Thayer Martin medium and subsequent identification by Gram stain, colonial morphology, positive oxidase, and rapid carbohydrate utilisation test.

Bacterial species closely related to $N$ gonorrhoeae were used in specificity studies and included $N$ pharyngis NCTC $4591, N$ flavescens NCTC 8263, $N$ caviae NCTC 10293, $N$ cinerea NCTC 10294, $N$ denitrificans NCTC 10295, $N$ canis NCTC 10296, $N$ cuniculi NCTC 10297, $N$ elongata NCTC $10660, N$ mucosa var mucosa NCTC 10774, $N$ ovis NCTC 11018, $N$ lactamica ATCC 23970, and a clinical isolate of $N$ meningitidis. Additional bacterial strains representing different species that are often found as genital commensals, including members of the genera Corynebacterium, Lactobacillus, Streptococcus, Staphylococcus, Acinetobacter, Moraxella, Branhamella, and members of the family Enterobacteriaceae were also used. The NCTC strains were kindly provided 
by the Gonococcus Reference Unit, Public Health Laboratory, Bristol and the other strains were obtained from the Queen Mary Hospital Clinical Microbiology Laboratory, Hong Kong.

\section{Clinical specimens}

Clinical specimens were collected from men and women with acute urethritis attending a sexually transmitted disease clinic in Guangzhou, China. Two urethral swabs from the male and two cervical swabs from the female were taken with phosphate buffered saline pre-wet swabs. One swab was inoculated directly onto modified Thayer Martin medium, incubated in $\mathrm{CO}_{2}$, and any suspected organisms were identified following the above procedure. The other swab was stored frozen at $-20^{\circ} \mathrm{C}$ except during transport to Hong Kong.

\section{Specimen processing for DNA amplification}

Bacterial DNA from $N$ gonorrhoeae strains, other Neisseria species, and genital commensals was extracted as described below. A bacterial suspension in water was made from an overnight cultured plate to give about $10^{8} \mathrm{cfu} / \mathrm{ml}$. Of the bacterial suspension, $50 \mu \mathrm{l}$ was used for each extraction and the following reagents were added sequentially to the suspension giving a final concentration of $1 \mathrm{M} \mathrm{NaCl}, 1 \mathrm{M} \mathrm{NaOH}$ and $1 \%$ sodium dodecyl sulphate. The contents were mixed and boiled for one minute, then neutralized with two volumes of $1 \mathrm{M}$ TRIS pH 7. The DNA was extracted once with phenol-TRIS, once with phenol-chloroform, and then precipitated with ethanol. The extracted DNA was resuspended in $30 \mu \mathrm{l}$ of sterile distilled water or TRIS-EDTA. For clinical specimens from China, each was suspended in $2 \mathrm{ml}$ phosphate buffered saline and vortexed for one minute to release the material from swab. The swab was removed and the suspension centrifuged for five minutes at $2-3000 \mathrm{rev} / \mathrm{min}$ to pellet cells. After removing the supernatant by aspiration, the cells were resuspended in 100 $\mu \mathrm{l} 1 \times$ PCR buffer with non-ionic detergent Tween $200.45 \%$ and proteinase $\mathrm{K}(200 \mu \mathrm{g} / \mathrm{ml})$. The cell suspension was incubated at $50-60^{\circ} \mathrm{C}$ for one hour, then heated to $95^{\circ} \mathrm{C}$ for ten minutes to inactivate the proteinase $\mathrm{K}$.

\section{Selection of PCR primers}

Sequence data on the $c p p B$ gene carried on both the chromosome and the $4.2 \mathrm{~kb}$ cryptic plasmid of $N$ gonorrhoeae was used to select two 20-mer oligonucleotide primers designated HO1 (5'GCTACGCATACCCGCGTTGC3') and $\mathrm{HO} 3$ (5'CGAAGACCTTCGAGCAGACA3'). The expected length of the amplified product of the target sequence with these primers was $390 \mathrm{bp}$. It was known from the restriction map of the target sequence that the restriction enzyme MspI would cut within the amplified product to give two fragments of 250 and 140 bp respectively and so it was used to confirm the specificity of the amplified product.

\section{PCR amplification}

Amplification was performed in $100 \mu \mathrm{l}$ reaction volumes containing: $50 \mathrm{pmol}$ of each oligonu- cleotide primer (HO1 and HO3); $200 \mu \mathrm{M}$ each of dATP, dCTP, dTTP, and dGTP; $1 \times$ PCR reaction buffer $(50 \mathrm{mM} \mathrm{KCl}, 10 \mathrm{mM}$ TRIS $\mathrm{pH}$ $8.3,100 \mu \mathrm{g} / \mathrm{ml}$ bovine serum albumin, $1.5 \mathrm{mM}$ $\mathrm{MgCl}_{2}$ ); and a $10 \mu \mathrm{l}$ volume of DNA. For DNA from clinical swabs, $50 \mu$ l of proteinase $K$ treated suspension was used and a $100 \mu$ l reaction volume was made up with the same constituent as described for DNA from bacteria. The tubes were mixed before overlaying with a drop of mineral oil. Forty cycles of amplification were performed in a DNA thermal cycler (Perkin-Elmer Cetus). Each cycle consisted of a 30 second denaturation step at $94^{\circ} \mathrm{C}$, a one minute annealing step at $55^{\circ} \mathrm{C}$, and a 30 second extension step at $74^{\circ} \mathrm{C}$.

Amplified product $(10 \mu \mathrm{l})$ was analysed by electrophoresis in a $2 \%$ agarose gel using standard methods. ${ }^{11}$ The ethidium bromide stained gel was examined under ultraviolet light for the presence of a $390 \mathrm{bp}$ fragment. If a fragment of the expected size was present, $5 \mu \mathrm{l}$ of the product was digested with $5 \mathrm{U}$ of $M s p \mathrm{I}$ (Boehringer) at $37^{\circ} \mathrm{C}$ for one to two hours, each in a final volume of $20 \mu \mathrm{l}$ of $1 \times$ reaction buffer provided by the manufacturer. The digested product was again electrophoresed and examined under ultraviolet light for two fragments of sizes 250 and 140 bp respectively.

\section{Results}

To evaluate the specificity of the selected primers (HO1 and HO3), DNA was extracted from 12 non-gonococcal Neisseria species, 18 genital commensal strains and $33 N$ gonorrhoeae strains (table 1). After a 40-cycle PCR reaction, only $N$ gonorrhoeae DNA was amplified (fig 1) to give a product of the expected fragment size $(390 \mathrm{bp}) . N$ denitrificans DNA also gave an amplified product, but the size was about 190 bp (fig 2). Apart from $N$ denitrificans, none of the non-gonococcal

Table 1 Bacteria used in specificity test for the PCR assay of $\mathrm{N}$ gonorrhoeae

\begin{tabular}{|c|c|c|}
\hline Organism & $\begin{array}{l}\text { No of isolates } \\
\text { tested }\end{array}$ & $\begin{array}{l}\text { No with } \\
\text { positive PCR }\end{array}$ \\
\hline Ngonorrhoeae & 33 & 33 \\
\hline$N$ meningitidis & 1 & 0 \\
\hline N lactamica ATCC 23970 & 1 & 0 \\
\hline N pharynis NCTC 10293 & 1 & 0 \\
\hline$N$ flavescens NCTC 8263 & 1 & 0 \\
\hline$N$ caviae NCTC 10293 & 1 & 0 \\
\hline$N$ cinerea NCTC 10294 & 1 & 0 \\
\hline N denitrificans NCTC 10295 & 1 & 0 \\
\hline$N$ canis NCTC 10296 & 1 & 0 \\
\hline N cuniculi NCTC 10297 & 1 & 0 \\
\hline \multirow{2}{*}{\multicolumn{3}{|c|}{$\begin{array}{l}\text { Nelongata NCTC } 10660 \\
N \text { mucosa var mucosa }\end{array}$}} \\
\hline & & \\
\hline NCTC 10774 & 1 & $\mathbf{0}$ \\
\hline$N$ ovis NCTC 11018 & 1 & 0 \\
\hline Cornebacterium sp & 1 & 0 \\
\hline Lactobacillus sp & 1 & 0 \\
\hline S. aureus & 1 & 0 \\
\hline S. epidermidis & 2 & $\mathbf{0}$ \\
\hline S. agalactiae & 1 & 0 \\
\hline \multicolumn{3}{|l|}{ Alpha-haemolytic } \\
\hline Streptococcus spp. & 1 & $\mathbf{0}$ \\
\hline Acinetobacter anitratus & 5 & 0 \\
\hline Acinetobacter lwoffii & 1 & $\mathbf{0}$ \\
\hline Moraxella sp & 1 & $\mathbf{0}$ \\
\hline Branhamella catarrhalis & 1 & 0 \\
\hline Klebsiella sp & 1 & 0 \\
\hline Enterobacter cloacae & 1 & $\mathbf{0}$ \\
\hline Escherichia coli & 1 & 0 \\
\hline
\end{tabular}

Positive PCR reaction is indicated by the presence of a $390 \mathrm{bp}$ amplified fragment and on digestion with Msp I gives two fragments of sizes 250 and $140 \mathrm{bp}$ respectively. 


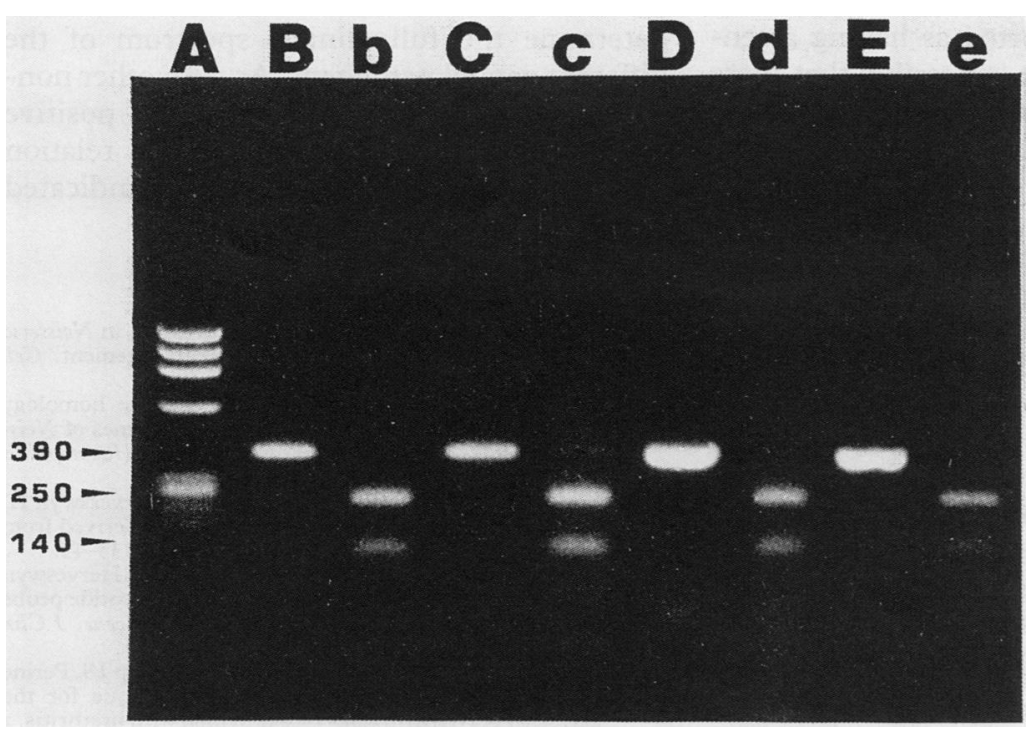

Figure $1 \quad P C R$ of representative samples from patients with a positive gonococcal culture result (lanes $B-E$ ). ( $A$ ) Size marker $\emptyset X 174$ digested with HaeIII. (B-E) $P C R$ products (390 bp) of clinical swabs containing $N$ gonorrhoeae. (b-e) corresponding DNA fragments (250 bp and $140 \mathrm{bp}$ ) of MspI digested PCR product.

Neisseria strains and genital commensals showed any amplified product. All the $33 \mathrm{~N}$ gonorrhoeae strains tested were amplified and the product contained the predicted internal restriction enzyme site for $M s p \mathrm{I}$, yielding a 250 bp and a $140 \mathrm{bp}$ fragment after digestion (fig 1).

For the sensitivity of the reaction, DNA was extracted from serial dilutions of a bacterial suspension prepared from overnight plate culture and an amplified product of $390 \mathrm{bp}$ was detected at approximately $500 \mathrm{cfu}$ of Neisseria gonorrhoeae.

To demonstrate the detection of $N$ gonorrhoeae in clinical specimens, urethral swabs were collected from 52 patients. Of these, 34 were culture and PCR positive, two were only PCR positive, and 16 were both culture and PCR negative, giving a sensitivity of $100 \%$ and

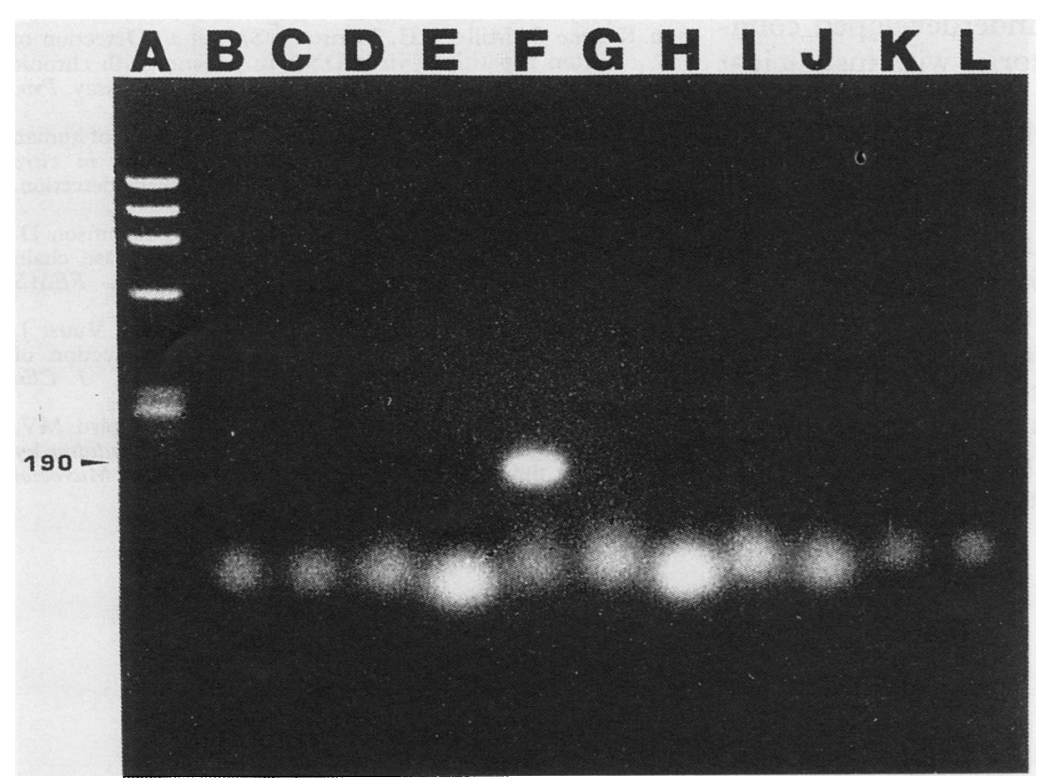

Figure $2 P C R$ results of DNA extracted from cultures of non-gonococcal Neisseria species. (Lanes $A-L$ ) $0 X 174-H a e I I I$ size marker, $N$ pharyngis, $N$ flavascens, $N$ caviae, $N$ cinerea, $N$ denitrificans, $N$ lactamica, $N$ cuniculi, $N$ elongata, $N$ mucosa, $N$ ovis, $N$ meningitidis respectively. specificity of $88.9 \%$ respectively. Digestion of the PCR amplified product with $M s p$ I yielded fragments of the predicted sizes.

\section{Discussion}

Selection of two primers which will amplify a specific sequence of the organism is a crucial step in the success of the PCR assay. In the present study we targeted the $c p p B$ gene since a separate copy was present in the genome of all $N$ gonorrhoeae strains tested. The $c p p B$ gene originates from the $4.2 \mathrm{~kb}$ cryptic plasmid of $N$ gonorrhoeae which was found in whole or part, integrated in the chromosome of all gonococcal strains tested. ${ }^{7}$ There are two variants of the cryptic plasmid, one had a deletion of $54 \mathrm{bp}$ within the $c p p B$ gene. Both the deleted and the undeleted version of the $c p p B$ gene may be found as a separate copy in the gonococcal genome, including the strains lacking plasmid. Therefore, when selecting for the primer sequence, the possibly deleted region of $c p p B$ gene was not included in the amplified region and the two chosen 20-mer oligonucleotide primers almost marked the entire length of the remaining $c p p B$ gene sequence.

For confirmation of the specificity of the amplified product, the presence of a restriction site within the amplified sequence was shown. This protocol was used instead of Southern hybridisation with a specific probe because of the possibility of clinical application of this assay and the use of hybridisation for confirmation may lengthen the time for diagnosis by another day.

Optimal conditions for the PCR were determined using crude DNA extracted from serial dilutions of gonococcal culture and it was shown that sensitivity of the assay was $500 \mathrm{cfu}$ of $N$ gonorrhoeae. Using the cryptic-derived DNA probe, Torres et al demonstrated a similar sensitivity of $500 \mathrm{cfu}^{10}$ Sensitivity of the PCR assay can be further increased if the method of detection is by probe hybridisation instead of visualisation with the ethidium bromide stained gel.

The specificity test for the chosen primers indicated that the assay would only give a fragment of expected size with $N$ gonorrhoeae. Although the cryptic plasmid of $N$ gonorrhoeae cross-reacts with plasmids from $N$ meningitidis and $N$ lactamica, this was not detected with our PCR assay. However, only one strain of each species was tested. There was no cross-reaction with any of the non-gonococcal Neisseria strains or other genital flora tested.

For application of this assay to clinical samples, only urethral swabs and cervical swabs have so far been tested. Using culture as the "gold standard", the sensitivity, specificity, PPV, and NPV for this test would be $100,88.9$, 94 , and $100 \%$ respectively (table 2 ). The 'gold

Table $2 P C R$ results of clinical swabs compared with culture

\begin{tabular}{llc}
\hline & Culture positive & Culture negative \\
\hline PCR positive & 34 & 2 \\
PCR negative & 0 & 16 \\
\hline
\end{tabular}

PCR assay: sensitivity $100 \%$, specificity $88.9 \%$, positive predictive value $94.4 \%$, negative predictive value $100 \%$. 
standard' has been reported as having a sensitivity of $85-95 \%^{12}$ so it is possible that there were false negatives for the culture method which would lead to an underestimation of the specificity of the PCR. The two specimens which were PCR positive and culture negative were found to be positive with Gonozyme (Abbot Laboratories) (results not shown). Though Gonozyme is well known to have false positive results and PCR may also give false positives due to contamination, it is unlikely in these cases. As PCR is detecting the gonococcal DNA and Gonozyme is detecting its antigen, if two tests are positive concurrently it is likely that the results in question are genuine detection of gonococci in specimens. Nevertheless, the possibility of these two specimens giving false positive results with both tests should not be overlooked.

This $c p p B$ gene sequence was chosen as primer due to its presence even on the chromosome of plasmid-free strains, thus overcoming the limitation of using cryptic plasmid as probe in DNA hybridisation for diagnosis of gonococcal infection. In this study, we were unable to test this hypothesis as plasmid-free strains have so far not been encountered in Asia ${ }^{13}$ and we have failed to obtain plasmid-free strains from other workers. We are thus unable to say that this PCR assay is universal for all gonococci. More plasmid-free strains will have to be tested with this assay before it can be used as a reliable diagnostic tool, but our results are promising. It should be investigated whether this PCR method is more useful than the existing enzyme immunoassay (Gonozyme, Abbott Laboratories) or other DNA probes in the accurate assessment of asymptomatic and symptomatic gonococcal infections.

Frozen swabs were used and also swabs which had been stored frozen for one month, and the PCR result was not affected. With the durability of DNA under such conditions, it is possible for specimens to be sent to distant laboratories for investigation. This would be particularly useful for underdeveloped countries or for small laboratories with insufficient facilities.

With the recent development of the PCR, more sensitive DNA probes have been produced and used to detect many of the common agents of sexually transmitted disease, namely Chlamydia trachomatis, ${ }^{14}$ human papillomavirus, ${ }^{15}$ hepatitis B virus, ${ }^{16}$ human immunodeficiency virus, ${ }^{17}$ Mycoplasma genitalium $^{1819}$ and Treponema pallidum. ${ }^{20}$ Publication of primer sequences and the evaluation of primers for these organisms could result in multiple probing systems which can be used to determine the full clinical spectrum of the different genital pathogens. As with other noncultural methods the significance of positive results must be carefully assessed in relation to the activity or otherwise of the indicated organism.

1 Meyer TF, Mlawer N, So M. Pilus expression in Neisseria gonorrhoeae invo

2 Koomey JM, Falkow S. Nucleotide sequence homology between the immunoglobulin A1 protease genes of Neisseria gonorrhoeae, Neisseria meningitidis and Haemophilus influenzae. Infect Immun 1984;43:101-4.

3 Roussau R, Vanmechelen E, De Ley J, van Herverswyn H. Specific Neisseria gonorrhoeae DNA-probes derived from Specific Neisseria gonorrhoeae DNA-probes derived
ribosomal RNA. J Gen Microbiol 1989;135:1735-45.

4 Roussau $R$, Duhamel $M$, van Dyck E, Piot $P$, van Herveswyn $H$. Evaluation of an rRNA-derived oligonucleotide probe for culture confirmation of Neisseria gonorrhoeae. J Clin Microbiol 1990;25(5):944-8.

5 Totten PA, Holmes KK, Handsfield HH, Knapp JS, Perine PL, Falkow S. DNA hybridisation technique for the detection of Neisseria gonorrhoeae in men with urethritis. Infect Dis 1983;148:462-71.

6 Sparling PF, Biswas G, Graves J, Blackman E. Plasmids of the gonococcus. In: Levi SB, Clowes RC, Kloenig EL, eds. Molecular biology, pathogenicity and ecology of baceds. Molecular biology, pathogenicity and ecology
terial plasmids. New York: Plenum, 1981:237-46.

7 Hagblom P, Korch C, Jonsson A, Normark S. Intragenic variation by site-specific recombination in the cryptic variation by site-specific recombination in the cryptic 1986;167:231-7.

8 Ison CA, Bellinger CM, Walker J. Homology of cryptic plasmid of Neisseria gonorrhoeae with plasmids from Neisseria meningitidis and Neisseria lactamica. J Clin Pathol 1986;39:1119-23.

9 Korch C, Hagblom P, Ohman H, Goransson M, Normark S Cryptic plasmid of Neisseria gonorrhoeae: the complete nucleotide sequence and genetic organisation. $J$ Bacteriol 1985;163:430-43.

10 Torres MJ, Cano R, Palomares JC. Evaluation of a DNA probe of plasmid origin for the detection of Neisseria gonorrhoeae in culture and clinical specimens. Mol Cell Probes 1991;5(1):49-54.

11 Sambrook J, Fritsch EF, Maniatis T. Molecular cloning: laboratory manual, 2nd ed. Cold Spring Harbor: Cold Spring Harbor, Laboratory, 1989.

12 Stamm WE. Diagnosis of Neisseria gonorrhoeae and Chlamydia trachomatis using antigen detection methods. Diagn Microbiol Infect Dis 1985;4:985-95.

13 Perine PL, Totten PA, Holmes KK, et al. Evaluation of a DNA-hybridisation method for the detection of African and Asian strains of $N$ gonorrhoeae in men with urethritis $J$ Infect Dis 1985;152:59-63.

14 Palmer HM, Gilroy CB, Thomas BJ, Hay PE, Gilchrist C, Taylor-Robinson D. Detection of Chlamydia trachomatis by the polymerase chain reaction in swabs and urine from men with non-gonococcal urethritis. J Clin Pathol 1991;44:321-5.

15 Shibata DK, Arnheim N, Martin WJ. Detection of human papilloma virus in paraffin-embedded tissue using the papilloma virus in paraffin-embedded tissue using the

16 Kaneko S, Miller RH, Feinstone SM, et al. Detection of serum hepatitis B virus DNA in patients with chronic hepatitis using the polymerase chain reaction assay. Proc hepatitis using the polymerase chain
Natl Acad Sci USA 1989;86:312-6.

17 Kwok S, Mack DH, Ullis KB, et al. Identification of human immunodeficiency virus sequences by using in vitro enzymatic amplification and oligomer cleavage detection. JVirol 1987;61:1690-4.

18 Palmer HM, Gilroy CB, Furr PM, Taylor-Robinson D. Development and evaluation of the polymerase chain reaction to detect Mycoplasma genitalium. FEMS Microbiol Lett 1991;77:199-203.

19 Jensen JS, Uldum SA, Sondergard-Andersen J, Vuust J, Lind $\mathbf{K}$. Polymerase chain reaction for detection of Mycoplasma genitalium in clinical samples. $J$ Clin Microbiol 1991;29(1):46-50.

20 Burstain JM, Grimprel E, Lukehart SA, Norgard MV Radolf JD. Sensitive detection of Treponema pallidum by using the polymerase chain reaction. J Clin Microbiol using the polym $1991 ; 29(1): 62-9$. 